\title{
THE EFFECT OF ACIDIFICATION ON GROWTH AND PHOTOSYNTHESIS RATE OF SEAGRASS Thalassia hemprichii (Ehrenberg.) Ascherson
}

\section{PENGARUH ASIDIFIKASI TERHADAP LAJU PERTUMBUHAN DAN FOTOSINTESIS LAMUN Thalassia hemprichii (Ehrenberg.) Ascherson}

\author{
Bq Tri Khairina Ilhami ${ }^{1}$, Mujizat Kawaroe ${ }^{1}$, Hefni Effendi $^{2,3 *}$, \\ \& Neviaty Putri Zamani ${ }^{1}$ \\ ${ }^{1}$ Department of Marine Science and Technology, Faculty of Fisheries and Marine Sciences- \\ IPB University, Bogor, 16680, Indonesia \\ ${ }^{2}$ Departement of Managment Water Resources, Faculty of Fisheries and Marine Sciences- \\ IPB University, Bogor, 16680, Indonesia \\ ${ }^{3}$ Center for Environmental Research, PPLH Building $2^{\text {nd }}-4^{\text {th }}$ Floor, Bogor, 16680, Indonesia \\ *E-mail: hefni_effendi@yahoo.com
}

\begin{abstract}
Seagrass is a water plant that has flowers and ability to adapt to live and grow in the sea like a terrestrial plant. The survival of seagrass is greatly influenced by physical and chemical parameters of waters, such as $\mathrm{pH}$, temperature, and salinity. The Intergovernmental Panel on Climate Change (IPCC) report by the end of $21^{\text {st }}$ century, $\mathrm{CO}_{2}$ in the atmosphere has doubled along with the industrial development. The increase in $\mathrm{CO}_{2}$ in the atmosphere causes ocean acidification, it can change the chemical structure and decrease the $\mathrm{pH}$ of sea water. The low $\mathrm{pH}$ of sea water influences plant phisiology such as the inhibition of photosynthesis and growth. The purpose of this study is to examine the effect of $\mathrm{pH}$ on the growth and photosynthesis rate of seagrass Thalassia hemprichii. The study used Completely Randomized Design with 3 treatments control (8.10-8.50), medium pH (7.76$8.00)$ and low $\mathrm{pH}(7.50-7.75)$ in 5 replicates. The results showed that growth rate, photosynthetic rate and chlorophyll content has a bigger value on control treatment than the low $\mathrm{pH}$ treatment. The ANOVA test results were not significant for all treatment variables and had a negative impact on the survival of seagrass.
\end{abstract}

Keywords: acidification, chlorophyll, photosynthesis rate, Thalassia hemprichii

\section{ABSTRAK}

Lamun merupakan tanaman air yang memiliki bunga dan kemampuan beradaptasi untuk hidup dan tumbuh di laut seperti tanaman terestrial. Kelangsungan hidup lamun sangat dipengaruhi oleh parameter fisik dan kimia perairan, seperti $\mathrm{pH}$, suhu, dan salinitas. Intergovernmental Panel on Climate Change (IPCC) melaporkan pada akhir abad 21, $\mathrm{CO}_{2}$ di atmosfer selalu meningkat seiring dengan perkembangan industri. Peningkatan $\mathrm{CO}_{2}$ di atmosfer menyebabkan terjadinya asidifikasi laut sehingga dapat mengubah struktur kimia dan pH air laut. Rendahnya pH air laut berpengaruh terhadap fisiologi tumbuhan seperti terhambatnya proses fotosintesis dan pertumbuhan. Tujuan penelitian ini adalah untuk menguji pengaruh $\mathrm{pH}$ terhadap pertumbuhan dan laju fotosintesis lamun Thalassia hemprichii. Penelitian ini menggunakan Rancangan Acak Lengkap dengan 3 perlakuan yaitu kontrol $(8,10-8,50)$, pH sedang $(7,76-8,00)$ dan $p H$ rendah $(7,50-7,75)$ dalam 5 ulangan. Hasil penelitian menunjukkan bahwa laju pertumbuhan, laju fotosintesis dan kandungan klorofil memiliki nilai lebih besar pada kontrol dibandingkan dengan perlakuan pada $\mathrm{pH}$ sedang dan rendah. Hasil uji ANOVA tidak signifikan untuk semua variabel perlakuan dan memiliki dampak negatif pada kelangsungan hidup lamun.

Kata kunci: asidifikasi, klorofil, laju fotosintesis, Thalassia hemprichii 


\section{INTRODUCTION}

By the end of the $21^{\text {st }}$ century it is estimated that carbon dioxide $\left(\mathrm{CO}_{2}\right)$ in the atmosphere has doubled along with industry development and increased usage of fossil energy such as coal, oil and gas (Chen \& Millero, 1979; IPCC, 2007; Revelle \& Suess, 1957). This condition can increase $\mathrm{CO}_{2}$ in the atmosphere by nearly $40 \%$ and decrease the ocean $\mathrm{pH}$ by 0.3-0.4 units (Brouns, 1985; Caldeira \& Wickett, 2003; Feely et al., 2004). Orr et al. (2005) modeled a decrease in $\mathrm{pH}$ by 7.949 in 2050 and 7.824 in 2100 . The impact that can be generated from the increase of $\mathrm{CO}_{2}$ in atmosphere is sea acidification (Turley, 2008). Acidification may cause chemical changes of carbonate in the relative proportions of $\mathrm{CO}_{2}$, bicarbonate $\left(\mathrm{HCO}_{3}{ }^{-}\right)$ and carbonate $\left(\mathrm{CO}_{3}{ }^{2-}\right)$ to shift the total dissolved inorganic carbon from $\mathrm{CO}_{3}{ }^{2-}$, to $\mathrm{HCO}_{3}{ }^{-}$(carbonic acid) and $\mathrm{CO}_{2}$ (Ciais et al., 2014). Water conditions at low $\mathrm{pH}$ can inhibit photosynthesis, inhibit growth, decrease immune response, witness fertilization and calcification of organisms (Kurihara et al., 2004; Brothers et al., 2016). Ow et al. (2015) revealed that acidification has an impact on photosynthesis and seagrass productivity.

Seagrass is a water plant that has flowers and adaptability to live and grow in the sea like a terrestrial plant (Kawaroe et $a l .$, 2016). The seagrass ecosystem has many important roles, such as habitat and shelter of various biota, nursery ground, spawning ground and stabilizing aquatic sediments (Guinotte \& Fabry, 2008; Koch et al., 2012; Christianen et al., 2013; Riniatsih \& Endrawati, 2013). The seagrass ecosystem also plays an important role in the coastal carbon cycle (Oreska et al., 2017). One of seagrass species $T$. hemprichii known as dugong grass is a dominant species that can be found almost in all Indonesian waters and become key species of tropical seagrass in the Indo-Pacific region (Mukai, 1993).
Due to the important role of seagrass ecosystem makes several studies have been conducted to determine the response of acidification. Acidification can increase photosynthesis in Zostera marina and Phyllospadix torreyi (Beer et al., 2002; Koch et al., 2012), biomass changes and increased productivity of $T$. testudinum, Halophila uninervis, Cymodocea serrulata (Campbell \& Fourqurean, 2013; Durako \& Sackett, 1993; Ow et al., 2015). Based on several literature studies above, it is necessary for further study to determine the effect of acidification on growth rate and photosynthesis rate of $T$. hemprichii seagrass.

\section{MATERIALS AND METHODS}

The study was conducted from September to December 2017. T. hemprichii were taken in the Kepulauan Seribu while for transplantation and analysis of photosynthetic response was performed at the Marine Habitat Laboratory, Faculty of Fisheries and Marine Sciences, IPB University. Analysis of chlorophyll content was performed in the testing laboratory, Faculty of Agriculture, IPB University.

$T$. hemprichii was taken by digging the whole bud with the rhizome connected to the sediment. Afterwards the sample then was placed in a coolbox, then transferred to the aquarium at Marine Habitat Laboratory.

\subsection{Research Design}

The research was design using Completely Randomized Design (RAL). The aquarium was used as a container to grow 15 seagrasses for 3 treatments with 5 replications each. The treatment was $\mathrm{pH}$ in the range of 7.76-8.00 for medium level, low $\mathrm{pH}$ in the range of 7.50-7.75 and control. The position of the aquarium was placed randomly (Figure 1). The volume of sea water used is $29 \mathrm{~L}$. The $\mathrm{pH}$ adjustment was performed by adding $\mathrm{CO}_{3}^{2}-20.18 \mathrm{ppm}$ for the low $\mathrm{pH}$ treatment and $19.79 \mathrm{ppm}$ for the 

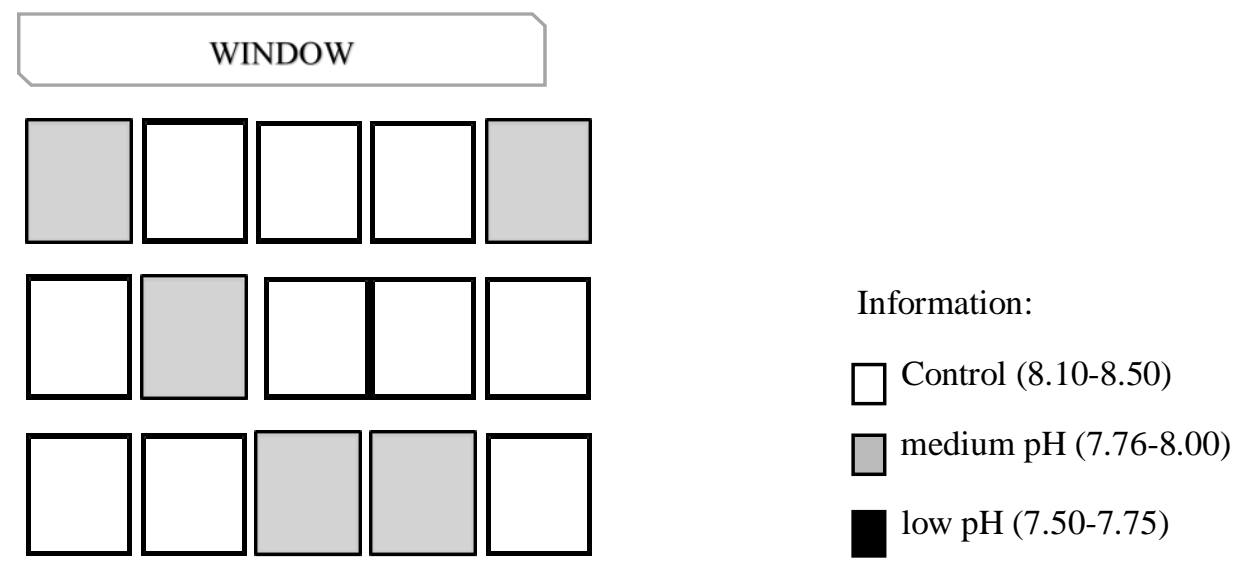

Figure 1. Experimental design of the study with two different $\mathrm{pH}$ range as treatment.

mean $\mathrm{pH}$, whereas the controls were added $19.20 \mathrm{ppm}$. LED light (Light Emitting Diode) P $800 \mathrm{~K}$ was mounted $30 \mathrm{~cm}$ above the aquarium surface. Lighting time was 12 hours light and 12 hours dark. Sea water was replaced every 2 weeks while NASA fertilizer is added to support seagrass growth every 1 week as much as $29 \mathrm{~mL}$.

Physical chemical parameters are measured daily at 03.00 PM. Water quality parameters measured in insitu that includes temperature using thermometer, salinitt using refractometer, and $\mathrm{pH}$ using $\mathrm{pH}$ meter.

\subsection{Growth Rate}

Growth rate of seagrass were measured by leaves length at certain intervals, in the beginning and end of the observation. The formula for growth rate is as follows (Short \& Coles, 2001):

$P=\frac{P_{t}-P_{0}}{\Delta_{t}}$

Information: $P=$ Leaf growth rate ( $\mathrm{mm} /$ day); $P_{t}=$ Leaf length at final measurement $(\mathrm{mm})$; $P_{0}=$ Leaf length at initial measurement $(\mathrm{mm}) ; \Delta t=$ Time measurement interval (days).

\subsection{Chlorophyll Content Analysis}

Determination of chlorophyll content was administered on young adult leaves of each seagrass samples. The seagrass leaves was dried and then weighed. The sample then was added $90 \%$ acetone solution. Each tube was filled with solvent up to $6 \mathrm{ml}$ then centrifuged at $4000 \mathrm{rpm}$ for 12 minutes. All samples were frozen to prevent heat and light degradation. A total of $1 \mathrm{ml}$ of supernatant was transferred into cuvette for spectrophotometry analysis at the wavelengths of 664.0 and $647.0 \mathrm{~nm}$. Calculations of chlorophyll content $(\mathrm{mg} / \mathrm{g})$ are as follows (Granger \& Izumi, 2001).

Chlorophyll $a=11.93 \mathrm{E}_{664}-1.93 \mathrm{E}_{647} \ldots .(2)$

Chlorophyll $b=20.36 \mathrm{E}_{647}-4.68 \mathrm{E}_{664} \ldots$. (3)

Information: $\quad \mathrm{E}_{664}=$ Correction of absorbance, (absorbance at wavelength of $664 \mathrm{~nm}$ - absorbance at $750 \mathrm{~nm}$ ).

\subsection{Photosynthesis Rate}

The seagrass leaves at each treatment were taken and dried before the measurement of photosynthesis rate. The measurement of photosynthesis rate were performed by LI-COR 6400XT Portable Photosynthesis System equipped with $\mathrm{CO}_{2}$ injector and LED light source. The leaves of seagrass were put into the chamber for a few seconds. Observational data were analyzed by program arrangement in the form of light intensity response curve $(\mathrm{PAR}=$ Photosynthesis Active Radiation) from 1-1200 
$\mu \mathrm{mol} \quad \mathrm{CO}_{2} \quad \mathrm{~m}^{-2} \mathrm{~s}^{-1}$ as abscissa and net photosynthesis as its coordinates so it obtain the curve of seagrass photosynthetic growth rate on control and every treatment observed (Soleh, 2017).

ANOVA was applied to test significant differences between experimental treatment (carbonate addition $\left(\mathrm{CO}_{3}{ }^{2-}\right)$ to decrease $\mathrm{pH}$ ) in all response variables (growth rate, chlorophyll and photosynthesis rate) at value of $\mathrm{P}=0.05$ (Suliyanto, 2012).

\section{RESULT AND DISCUSSION}

\subsection{Physics and Chemical Water Parameters}

Seagrass survival is influenced by physical and chemical factors of water directly or indirectly. Physical and chemical water parameters are presented in Table 1. The $\mathrm{pH}$ value of waters at control ranged from 8.07 to 8.48 . The $\mathrm{pH}$ range at $\mathrm{pH}$ treatment (7.76) is 7.75-7.83. The $\mathrm{pH}$ range at the $\mathrm{pH}$ treatment (7.58) is 7.57-7.65. The increase in $\mathrm{pH}$ is thought to be due to reduced $\mathrm{CO}_{2}$ due to photosynthetic activity.

Table 1. Physical-chemical water parameters.

\begin{tabular}{lccc}
\hline \multirow{2}{*}{ Parameters } & \multicolumn{3}{c}{ Treatment of $\mathrm{pH}$} \\
\cline { 2 - 4 } & Control & Medium & Low \\
\hline $\mathrm{pH}$ & 8.32 & 7.76 & 7.58 \\
Temperature & 28.68 & 28.66 & 28.70 \\
$\left({ }^{\circ} \mathrm{C}\right)$ & & & \\
Salinity (psu) & 32.48 & 32.89 & 32.60 \\
\hline
\end{tabular}

The temperature range of the controls are $27.5-29.6{ }^{\circ} \mathrm{C}$, for the medium $\mathrm{pH}$ treatment are $27.5-29.9{ }^{\circ} \mathrm{C}$ and for the low $\mathrm{pH}$ treatment are $27.4-29.6{ }^{\circ} \mathrm{C}$. Based on the temperature in Table 1, the temperature of waters on the control and treatment of $\mathrm{pH}$ (7.76) and $\mathrm{pH}$ (7.58) is still within the optimum range for growth and photosynthesis on $T$. hemprichii which is $27-30^{\circ} \mathrm{C}$ (Kondoy et al., 2014). Water temperatures that fall outside the normal range can still be tolerated by the seagrass plants but will disrupt the physiological process. The temperature range of $25-30^{\circ} \mathrm{C}$ will increase photosynthesis along with rising temperatures. If the temperature of the waters exceeds the optimum limit of seagrass growth it can lead to stress, death and loss of genetic biodiversity due to the high respiratory process compared to photosynthesis (Chefaoui et al., 2018; Staehr \& Borum, 2011).

The salinity of $T$. hemprichii in the controls is in the range of 30.4-34.4 psu. The $\mathrm{pH}$ treatment (7.76) is in the range of 30.634.8 psu while the $\mathrm{pH}$ treatment (7.58) is in the range of 30-35.2 psu. Based on the salinity value in Table 1 it shows that the salinity range in the control and treatment is still within the optimum salinity of 20-40 psu (Touchette \& Burkholder, 2000). Salinity that exceed the optimum limit causes stress on seagrass, it can reduce chlorophyll content, nutrient absorpsion, decreased leaf growth rate, morphological changes, photosystem function and death (Kuo \& Lin, 2010; Marin-Guirao et al., 2013). Based on Table 1 shows that temperature and salinity in the control and treatment of medium and low $\mathrm{pH}$ are at the optimum range for seagrass growth.

\subsection{Growth Rate of T. hemprichii}

Leaf length growth is the difference in leaves that grow within specified time intervals (30 days). Based on Figure 2, the average length of seagrass leaves in the control was $3.76 \mathrm{~mm} /$ day with the growth rate ranged from 2.07 to $4.63 \mathrm{~mm} /$ day. The average length of seagrass leaves in $\mathrm{pH}$ treatment (7.76) is $2.32 \mathrm{~mm} /$ day and growth rate is in the range of $0.33-6.33 \mathrm{~mm} /$ day. The $\mathrm{pH}$ treatment (7.58) has an average length of $2.21 \mathrm{~mm} /$ day with a hose value of $0.83-4.1 \mathrm{~mm} / \mathrm{day}$. The ANOVA test showed that the average leaf growth rate was not significantly different ( $\mathrm{P}>0.05)$ among treatments.

The growth rate of seagrass leaves is 
directly proportional to the content of chlorophyll and the rate of photosynthesis. The low rate of leaf growth in the treatment is suspected because that the seagrass is still adapting to the new environment. Seagrass growth is influenced by internal factors such as physiology, metabolism and external factors such as nutrient content of the substrate fertility and marine environmental parameters (Alexandre et al., 2012; Ow et al., 2015). These environmental factors affect the metabolism of carbon and nitrogen. Lack of nitrogen in the $\mathrm{pH}$ treatment (7.76) and $\mathrm{pH}$ (7.58) affects the formation of chlorophyll that interferes with the photosynthesis process and inhibits growth in seagrass leaves.

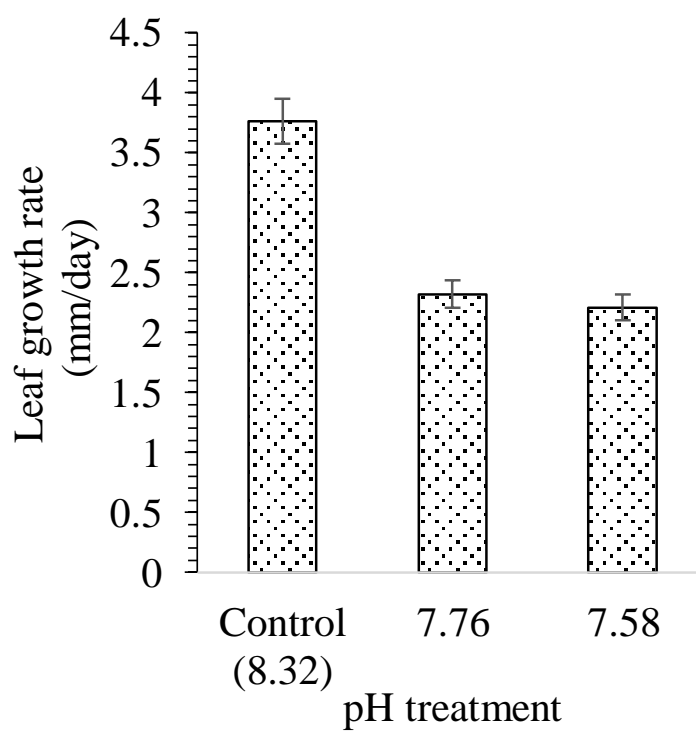

Figure 2. T. hemprichii leaf growth rate in control and treatment for 30 days.

\subsection{Content of Chlorophyll T. hemprichii}

Chlorophyll is a pigment owned by plants and plays a role in the process of photosynthesis. Chlorophyll absorbs and uses the energy of sunlight for the synthesis of oxygen $\left(\mathrm{O}_{2}\right)$ and carbohydrates of $\mathrm{CO}_{2}$ and water. Chlorophyll content on seagrass tissue can affect the physiological response. Seagrass plants contain only 2 chlorophyll pigments namely chlorophyll a and chlorophyll b. The difference of the chlorophyll pigment lies in the absorbed wavelength. Based on Figure 3 the average content of chlorophyll a and $b$ in the controls were 1.83 and $1.10 \mathrm{mg} / \mathrm{g}$ with a chlorophyll $\mathrm{a}$ in the range of $1.22-2.49 \mathrm{mg} / \mathrm{g}$ and chlorophyll b 0.76-1.47 mg/g. The $\mathrm{pH}$ treatment (7.76) average content of chlorophylls a and $b$ are 1.36 and $0.83 \mathrm{mg} / \mathrm{g}$ with of each chlorophyll is in the range of $1.09-2.33 \mathrm{mg} / \mathrm{g}$ and $0.75-0.83 \mathrm{mg} / \mathrm{g}$. The $\mathrm{pH}$ treatment (7.58) has an average of chlorophyll $\mathrm{a}$ and $\mathrm{b}$ of 0.91 and $0.56 \mathrm{mg} / \mathrm{g}$ with of each ranging from 0 to $1.66 \mathrm{mg} / \mathrm{g}$ and $0-1.06 \mathrm{mg} / \mathrm{g}$. The result of ANOVA analysis showed that average yield of chlorophyll content is not significant $(\mathrm{P}>$ $0.05)$.

The amount of chlorophyll in a plant will affect the photosynthesis and growth of seagrass. The low chlorophyll content of treatments especially in low and medium $\mathrm{pH}$ is seen from the color of the seagrass leaf form pale to black (Figure 4).

The amount of chlorophyll is determined by the availability of light, depth, type of seagrass, leaf age and nutrien (Wiginton \& McMillan, 1979; Lee et al., 2007; Clores \& Carandang, 2013). The color changes on the leaves of the seagrass are suspected caused by a stressful condition to the environment. Adaptation mechanisms on seagrass when stress will depend on the intensity, type and duration of the disturbance. When in a state of stress, the seagrass will lose the chlorophyll and carotenoid molecules so the leaf color will be different when the leaves are naturally aging (Duarte et al., 2012). The pheophytin reaction occurs when the plant is in an acidic $\mathrm{pH}$. In acidic conditions, chlorophyll will be very easily degraded and will form peophytin due to the shift of two hydrogen (H) atoms (Dwidjoseputro, 1994). The pressure from $\mathrm{H}$ atoms causes the loss of $\mathrm{Mg}^{2+}$ ions which is the main components of chlorophyll so that the color of the leaves in the medium and low $\mathrm{pH}$ treatment are brown 


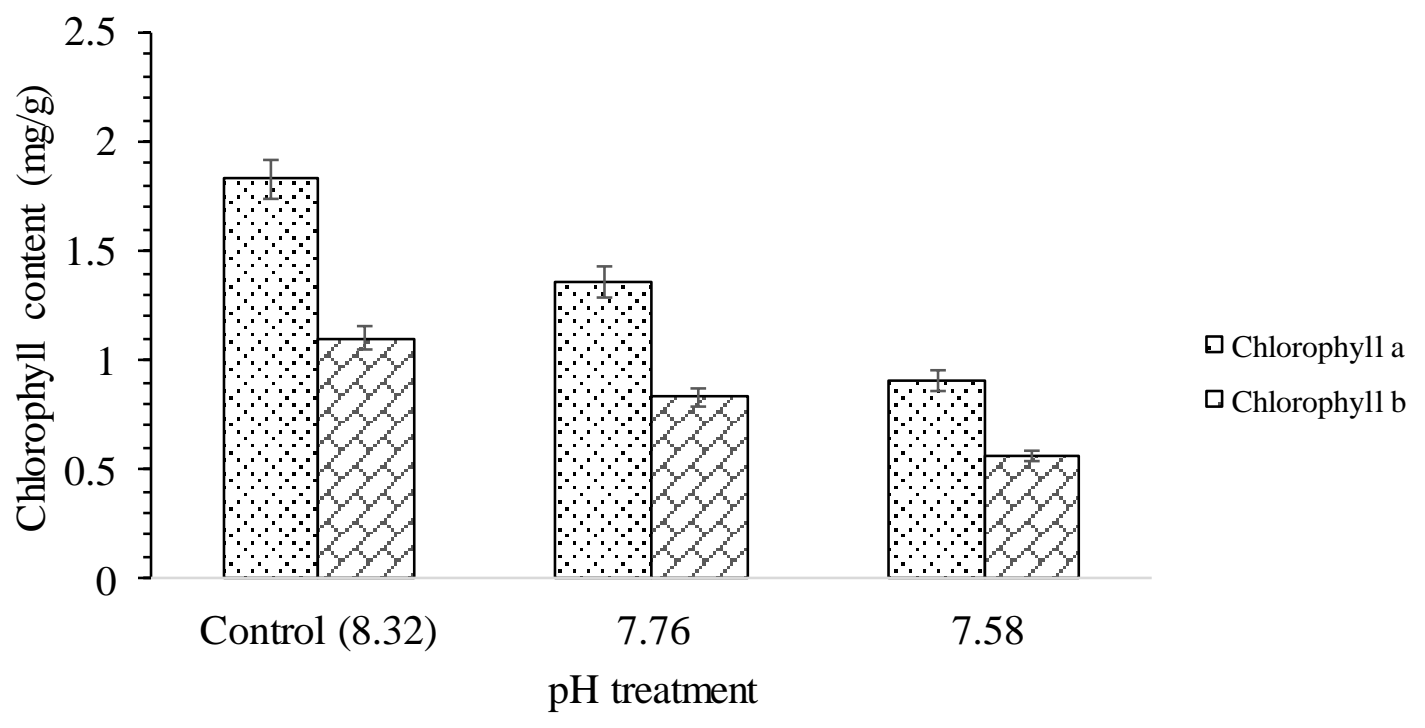

Figure 3. Chlorophyll content in control and treatment for 30 days.
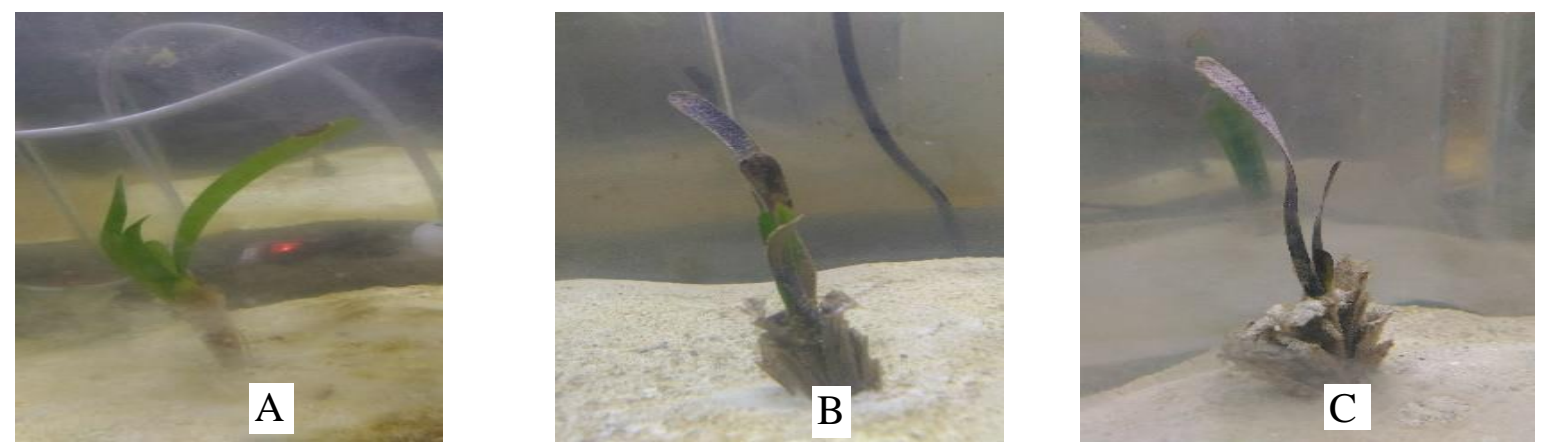

Figure 4. The condition and color of T. hemprichii leafs on control (A), $\mathrm{pH} 7.76$ (B) and pH 7.58 (C) for 30 days.

(Figure 4). Loss of chlorophyll content will inhibit the process of growth and photosynthesis.

\subsection{Photosynthetic Rate T. hemprichii}

The mean value of the photosynthetic rate (Figure 5) in the control of $19.11 \mu \mathrm{mol} \mathrm{CO} \mathrm{CO}^{-2} \mathrm{~s}^{-1}$ is in the range of 15.62-21.39 $\mu \mathrm{mol} \mathrm{CO}_{2} \mathrm{~m}^{-2} \mathrm{~s}^{-1}$. The mean value of photosynthesis rate in $\mathrm{pH}$ treatment (7.76) is $12.61 \mu \mathrm{mol} \mathrm{CO} 2 \mathrm{~m}^{-2} \mathrm{~s}^{-1}$ in the range $0-18.28 \mu \mathrm{mol} \mathrm{CO}_{2} \mathrm{~m}-2 \mathrm{~s}-1$ while at $\mathrm{pH}$ (7.58) the value is $12.31 \mu \mathrm{mol} \mathrm{CO} 2 \mathrm{~m}^{-2} \mathrm{~s}^{-1}$ and is in the range of $0-17.71 \mu \mathrm{mol} \mathrm{CO} 2 \mathrm{~m}^{-2}$ $\mathrm{s}^{-1}$. The ANOVA test showed an insignificant $\mathrm{pH}$ decrease $(\mathrm{P}>0.05)$ against the mean rate of photosynthesis. Seagrass capacity in response to changes in aquatic environments primarily to $\mathrm{pH}$ depletion depends on the availability of nutrients and light.

Factors that influence the rate of photosynthesis in addition to light and nutrient composition are chlorophyll content and tissue age. The rate of photosynthesis in the control was higher when compared to the treatment at $\mathrm{pH}(7.76)$ and $\mathrm{pH}$ (7.58), this corresponds to the chlorophyll content in each treatment. The low chlorophyll content of medium and low $\mathrm{pH}$ treatments caused a low rate of photosynthesis in seagrass $T$. hemprichii. This is because chlorophyll plays an important role in the absorption of free $\mathrm{CO}_{2}$ in the waters (Ariyati 
et al., 2007). The availability of $\mathrm{CO}_{2}$ in the waters affects the process of photosynthesis. Addition of $\mathrm{CO}_{3}{ }^{2-}$ results in reduced $\mathrm{CO}_{2}$ free in the waters and an increase in the amount of $\mathrm{O}_{2}$ (Susana, 1988).

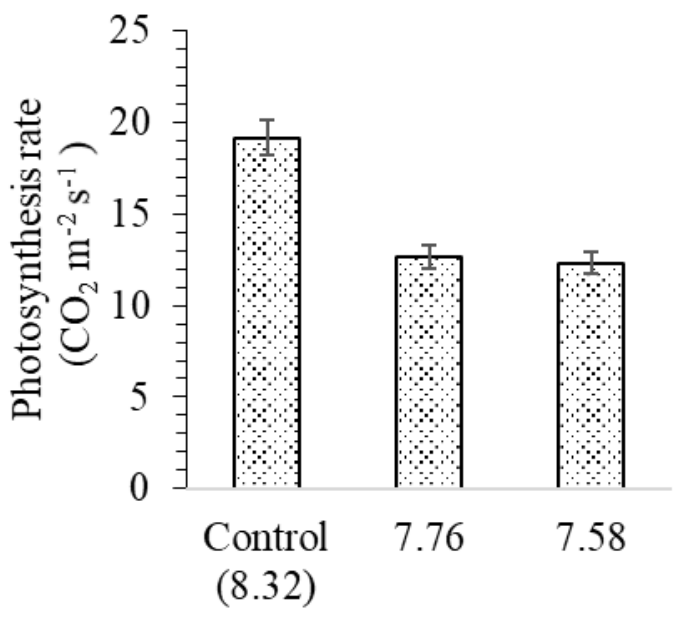

$\mathrm{pH}$ treatment

Figure 5. Photosynthetic rate of T. hemprichii in control and treatment for 30 days.

In the control treatment, seagrass will use $\mathrm{HCO}_{3}{ }^{-}$during photosynthesis which is abundant so that when photosynthesis takes place, seagrasses will use carbon from $\mathrm{HCO}_{3}$ - to replace $\mathrm{CO}_{2}$. The $\mathrm{HCO}_{3}$ is used by extracellular dehydration of $\mathrm{HCO}_{3}{ }^{-}$into $\mathrm{CO}_{2}$ through a carbonic anhydrase (CA) enzyme bound to the membrane (Uku et al., 2005).

\section{CONCLUSION}

The ANOVA test were not significantly different among treatments, however, growth rates, chlorophyll content, and photosynthetic rate of $T$. hemprichii seagrasses had greater value on the control when compared with lower $\mathrm{pH}$ treatment. Acidification has negative effect on growth rate, chlorophyll content and photosynthesis rate of $T$. hemprichii.

\section{REFERENCES}

Alexandre, A., J. Silva, P. Buapet, \& R. Santos. 2012. Effects of $\mathrm{CO}_{2}$ enrichment on photosynthesis, growth, nitrogen metabolism of the seagrass Zostera noltii. Ecol. Evol., 2(10): 2620-2630. http://doi.org/10.1002/ece3.333

Ariyati R.W., L. Sya'rani, \& E. Arini. 2007. Analisis kesesuaian perairan Pulau Karimunjawa dan Pulau Kemujan sebagai lahan budidaya rumput laut menggunakan sistem informasi geografis. J. Pasir Laut. 3(1): 27-45. DOI?

Beer, S., M. Bjork, F. Hellblom, \& L. Axelsson. 2002. Inorganic carbon utilization in marine angiosperms (seagrasses). Funct. Plant. Biol., 29(3): 349-354. http://doi.org/10.1071/PP01185

Brothers, C.J., J. Harianto, J.B. McClintock, \& M. Byrne. 2016. Sea urchins in a high $\mathrm{CO}_{2}$ world: the influence of acclimation on the immune response to ocean warming and acidification. Proceedings of the Royal Society, 283(1837): 1-10. http://doi.org/10.1098/rspb.2016.150 1

Brouns, J.J.W.M. 1985. A comparison of the annual production and biomass in three monospecific stands of the seagrass Thalassia hemprichii (Ehrenb.) aschers. Aquat. Bot., 23(2): 149-175. http://doi.org/10.1016/03043770(85)90062-2

Caldeira, K. \& M.E. Wickett. 2003. Oceanography: anthropogenic carbon and ocean pH. Nature, 425: 365. http://doi.org/10.1038/425365a

Campbell, J.E. \& J.W. Fouqurean. 2013. Effects of in situ $\mathrm{CO}_{2}$ enrichment on the structural and chemical characteristic of the seagrass 
Thalassia testudinum. Mar. Biol., 160: $1465-1475$.

http://doi.org/10.1007/s00227-0132199-3

Chefaoui, R.M., C.M. Duarte, \& E.A. Serrano. 2018. Dramatic loss of seagrass habitat under projected climate change in the Mediterranean Sea. Global Change Biology, 24(10): 4919-4928.

http://doi.org/10.1111/gcb.14401

Chen, G.T. \& F.J. Millero. 1979. Gradual increase of oceanic $\mathrm{CO}_{2}$. Nature, 277: 205-206.

http://doi.org/10.1038/277205a0

Christianen, M.J.A., J. van Belzen, P.M.J. Herman, M.M. van Katwijk, L.P.M. Lamers, P.J.M. van Leent, \& T.J. Bouma. 2013. Low-canopy seagrass beds still provide important coastal protection services. PLOS ONE, 8(5): e62413.

https://doi.org/10.1371/journal.pone. 0062413

Ciais, P., C. Sabine, G. Bala, L. Bopp, V. Brovkin, J. Canadell, A. Chhabra, R. DeFries, J. Galloway, M. Heimann, C. Jones, C. Le Quéré, R.B. Myneni, S. Piao, \& P. Thornton, 2014: Carbon and Other Biogeochemical Cycles. In: Climate Change 2013: The Physical Science Basis. Contribution of Working Group I to the Fifth Assessment Report of the Intergovernmental Panel on Climate Change [Stocker, T.F., D. Qin, G.-K. Plattner, M. Tignor, S.K. Allen, J. Boschung, A. Nauels, Y. Xia, V. Bex and P.M. Midgley (eds.)]. Cambridge University Press, Cambridge, United Kingdom and New York, NY, USA. 465-570 pp.

https://www.ipcc.ch/site/assets/uploa ds/2018/02/WG1AR5_Chapter06_FI NAL.pdf

Clores, M.A. \& J.A.V.I. Carandang. 2013. Chlorophyll content, productivity and biomass allocations of seagrass in Talim Bay, Lian, Batangas, Philippines. Proceedings of the International Academy of Ecology and Environmental Sciences, 3(3): 247-256.

Duarte, B., T. Couto, J.C. Marques, \& I. Cacador. 2012. Scirpus maritimus leaf pigment profile and photochemistry during senescene: implications on carbon sequestration. Plant Phys. Biochem., 57: 238-244. http://doi.org/10.1016/j.plaphy.2012. 05.019

Durako, M.J. \& W.M. Sackett. 1993. Effects of $\mathrm{CO}_{2}$ on the carbon isotropic composition of the seagrass Thalassia testudinum banks ex koning (Hydrocharitaceae). J. Exp. Mar. Biol. Ecol., 169: 167-180. http://doi.org/10.1016/00220981(93)90192-Q

Dwidjoseputro D. 1994. Pengantar Fisiologi Tumbuhan. Jakarta, Indonesia: Gramedia Pustaka Utama. 124 p.

Feely, R.A., C.L. Sabine, K. Lee, W. Berelson, J. Kleypas, \& F.J. Millero. 2004. Impact of antrophogenic $\mathrm{CO}_{2}$ on the $\mathrm{CaCO}_{3}$ system in the oceans. Science, 305(2): 362-366. http://doi.org/10.1126/science.10973 29

Granger, S. \& H. lizumi. 2001. Water quality measurement methods for seagrass habitat. In: Short FT, Coles RG, editor. Global Seagrass Research Methods, 2001: 393-406. https://doi.org/10.1016/B978044450891-1/50021-9

Guinotte, J.M. \& V.J. Fabry. 2008. Ocean acidification and its potential effects on marine ecosystems. Annals of the New York Academy Sciences, 1134(1): 320-342. http://doi.org/10.1196/annals.1439.0 13

Intergovernmental Panel on Climate Change (IPCC). 2007. Climate change 2007: Synthesis Report Climate Change 
2007: Synthesis Report. Contribution of Working Groups I, II and III to the Fourth Assessment Report of the Intergovernmental Panel on Climate Change [Core Writing Team, Pachauri, R.K and Reisinger, A. (eds.)]. IPCC, Geneva, Switzerland, $104 \mathrm{pp}$.

https://www.ipcc.ch/report/ar4/syr/

Kawaroe, M., A.H. Nugraha, \& Juraij. 2016. Ekosistem padang lamun. Bogor, Indonesia: IPB Press. 19 p.

Koch, M., G. Bowes, C. Ross, \& X.H. Zhang. 2013. Climate change and ocean acidification effects on seagrasses and marine microalgae. Global Change Biology, 19(1): 103132. http://doi.org/10.1111/j.13652486.2012.02791.X

Kondoy, K.I.F., E.Y. Herawati, M. Mahmudi, \& R. Azrianingsih. 2014. $\mathrm{CO}_{2}$ application as growth stimulator of seagrass, Thalassia hemprichii under laboratory conditions. J. Bio. Env. Sci, 5(6): 153-159.

https://innspub.net/volume-5number-6-december-2014-jbes/

Kuo, Y.M., \& H.J. Lin. 2010. Dynamic factor analysis of long-term growth trends of the intertidal seagrass Thalassia hemprichii in Southern Taiwan. Estuar, Coast. Shelf. Sci., 86(2): 225-236.

http://doi.org/10.1016/j.ecss.2009.11. 017

Kurihara, H., S. Shimode, \& Y. Shirayama. 2004. Sub-lethal effects of elevated concentration of $\mathrm{CO}_{2}$ on planktonic copepods and sea urchins. $J$. of Oceanography, 60: 743-750. https://doi.org/10.1007/s10872-0045766-X

Lee, K.S., S.R. Park, \& Y.K. Kim. 2007. Effects of irradiance, temperature, and nutrients on growth dynamics of seagrass: A review. J. Exp. Mar. Biol. Ecol., 350(1-2): 144-175. http://doi.org/10.1016/j.jembe.2007.0 6.016

Marin-Guirao, L., J.M. Sandova-Gil, J. Bernardeau-Esteller, J.M. Ruiz, \& J.L. $\quad 2013$. Responses of the Mediterranean seagrass Posidonia oceanica to hypersaline stress duration and recovery. Mar. Environ. Res., 84: 6075.

http://doi.org/10.1016/j.marenvres.20 12.12.001

Mukai, H. 1993. Biogeography of the tropical seagrasses in the western Pacific. Aust. J. Mar. Freshwater Res., 44(1): 1-17. http://doi.org/10.1071/MF9930001

Oreska, M.P.J., McGlathery, K.J., \& J.H. Porter. 2017. Seagrass blue carbon spatial patterns at the meadow-scale. PloS ONE, 12(4): e0176630. https://doi.org/10.1371/journal.pone. 0176630

Orr, J.C., V.J. Fabry, O. Aumont, L. Bopp, S.C. Doney, R.A. Feely, Gnanadesikan, N. Gruber, A. Ishida, F. Joos, R.M. Key, K. Lindsay, Maier-Reimer, R. Matear, P. Monfray, A. Mouchet, R.G. Najjar, G.K. Plattner, K.R. Rodgers, C.L. Sabine, J.L. Sarmiento, R. Schlitzer, R.D. Slater, I.J. Totterdel, M.F. Weiring, Y. Yamanaka, \& A. Yool. 2005. Anthropogenic ocean acidification over twenty-first century and its impact on calcifying organisms. Nature, 437(7059): 681686.

http://doi.org/10.1038/nature04095

Ow, Y.X., C.J. Collier, \& S. Uthicke. 2015. Responses of three tropical seagrass species to $\mathrm{CO}_{2}$ enrichment. Mar. Biol., 162(5): 1005-1017. http://doi.org/10.1007/s00227-0152644-6

Revelle, R. \& H.E. Suess. 1957. Carbon dioxide exchange between atmosphere and ocean and the 
question of an increase of atmospheric $\mathrm{CO}_{2}$ during the past decades. Tellus, 9(1): 18-27.

https://doi.org/10.1111/j.21533490.1957.tb01849.x

Riniatsih, I. \& H. Endrawati. 2013. Pertumbuhan lamun hasil transplantasi jenis Cymodocea rotundata di padang lamun Teluk Awur Jepara. Bul. Osea. Mar., 2: 3440.

http://doi.org/10.14710/buloma.v2i1. 6924

Short, F.T, \& C.M. Duarte. 2001. Methods for the measurement of seagrass and growth production. In: Short FT, Coles RG, editor. Global Seagrass Research Methods. Elsevier Science. 8: 155-182.

http://doi.org/10.1016/B978044450891-1/50009-8

Soleh, M.A. 2017. Faktor yang mendasari overestimasi pengukuran gas exchange tanaman dengan menggunakan Photosynthesis Analyzer Li-6400. J. Kultivasi, 16(1): 255-259.

http://doi.org/10.24198/kltv.v16i1.11 546

Staehr, P.A. \& J. Borum. 2011. Seasonal acclimation in metabolism reduces light requirements of eelgrass (Zostera marina). J. Exp. Mar. Biol. Ecol., 407(2): 139-146.

http://doi.org/10.1016/j.jembe.2011.0 5.031

Suliyanto. 2012. Analisis statistik pendekatan praktis dengan Microsoft
Excel (Statistical analysis of practical approaches with Microsoft Excel). Yogyakarta, Indonesia: Andi offset. $232 \mathrm{p}$.

Susana, T. 1988. Karbon dioksida. Oseana, 3(1): 1-11.

Touchette, B.W. \& J.M. Burkholder. 2000. Overview of the physiological ecology of carbon metabolism in seagrasses. J. Exp. Mar. Biol. Ecol., 250(1-2): 169-205.

http://doi.org/10.1016/s00220981(00)00196-9

Turley, C. 2008. Impacts of changing ocean chemistry in a high $\mathrm{CO}_{2}$ world. Min Mag, 72: 359-362.

http://doi.org/10.1180/minmag.2008. 072.1.359

Uku, J., S. Beer, \& M. Bjork. 2005. Buffer sensivity photosynthetic carbon utilisation in eight tropical seagrasess. Mar. Biol., 147: 10851090. http://doi.org/10.1007/s00227005-0019-0

Wiginton, J.R. \& C. McMillan. 1979. Chlorophyll composition under controlled light conditions as related to the distribution of seagrasses in Texas and the US Virgin Islands. Aquatic Botany, 6: 171-184. http://doi.org/10.1016/03043770(79)90060-3

Received : 17 December 2018

Reviewed : 1 December 2019

Accepted : 3 December 2020 